Sains Malaysiana 47(1)(2018): 19-25

http://dx.doi.org/10.17576/jsm-2018-4701-03

\title{
Fauna Diversity in Pitcher Plants at Setiam Hill, Bintulu, Sarawak, Malaysia
}

(Kepelbagaian Fauna dalam Tumbuhan Periuk Kera di Bukit Setiam, Bintulu, Sarawak, Malaysia)

\author{
M.T. MARINA*,C. JOHN KEEN, B.R. CAROLINE \& J. AFSAR
}

\section{ABSTRACT}

A study was carried out to determine the diversity and enumerate the fauna species related to five pitcher plant species at a selected area in Bukit Setiam Forest, Tatau, Bintulu, Sarawak, Malaysia. At the end of the study, six insect orders together with nematodes and Araneae were detected with different existence abundances and diversity. From the 901 total fauna trapped, $58.82 \%$ belonged to the order Hymenoptera, mainly of the ant species, followed by nematodes (21.64\%), Diptera (15.87\%), Coleoptera (1.66\%), Hemiptera $(0.89 \%)$, Blattaria $(0.44 \%)$ and finally, Lepidoptera $(0.33 \%)$ and Araneae $(0.33 \%)$. Significant differences $(\mathrm{p}<0.05)$ in the composition of insect trapped in pitcher plants were observed for the order Hymenoptera, Diptera, Lepidoptera, Hemiptera and even nematodes. Meanwhile, no significant difference was observed for Coleoptera, Blattaria and Araneae. There is a strong relationship between fauna and Nepenthes pitcher either as a prey, predator, a mutualistic relationship or parasites or also for a habitat to live or to reproduce.

Keywords: Borneo; fauna; Nepenthes; relationship; Setiam Hill

ABSTRAK

Satu kajian telah dijalankan untuk menentukan kepelbagaian dan menghitung spesies fauna yang berkaitan dengan lima spesies tumbuhan periuk kera di sebuah kawasan terpilih di Hutan Bukit Setiam, Tatau, Bintulu, Sarawak, Malaysia. Pada akhir kajian ini, enam tertib serangga bersama nematod dan Araneae telah dikesan dengan kewujudan kelimpahan dan kepelbagaian yang berbeza. Daripada 901 jumlah fauna yang terperangkap, 58.82\% adalah daripada tertib Hymenoptera, terutama daripada spesies semut, diikuti oleh nematod (21.64\%), Diptera (15.87\%), Coleoptera (1.66\%), Hemiptera (0.89\%), Blattaria (0.44\%) dan akhirnya, Lepidoptera (0.33\%) dan Araneae (0.33\%).Perbezaan yang signifikan ( $\mathrm{p}<0.05)$ dalam komposisi serangga terperangkap di dalam periuk kera dilihat bagi tertib Hymenoptera, Diptera, Lepidoptera, Hemiptera malahan nematod. Sementara itu, tiada perbezaan ketara diperhatikan untuk Coleoptera, Blattaria dan Araneae. Wujud satu hubungan yang kuat antara fauna dan periuk Nepenthes sama ada sebagai mangsa, pemangsa, hubungan mutualistik atau parasit dan juga sebagai habitat untuk hidup atau untuk berkembang biak.

Kata kunci: Borneo; Bukit Setiam; fauna; hubungan; Nepenthes

\section{INTRODUCTION}

Carnivorous pitcher plants of the genus Nepenthes are some of the most extraordinary plants in the world. Nepenthes belonging to the family Nepenthaceae, is represented by 81 species in the world (Adam 1995) and distributed from Madagascar, South East Asia, Southern China, Queensland, New Caledonia, New Guinea to Seychelles (Clarke 2001) with Borneo being the center of Nepenthes diversity (Clarke 1997).

Pitcher plants are climbers and scramblers, occupying terrestrial habitats and some growing epiphytically on trees. Pitcher plants adapted well to places where soil is thin or poor in nutrients, especially nitrogen, such as acidic bogs and rock outcroppings. These characteristics attributed to their carnivorous habit (Adam 2002). These carnivorous plants derive nutrients (but not energy) from trapping and consuming animals, typically insects and other arthropods. Pitcher plants also provide homes and breeding places for a number of other creatures. The pitcher is its own ecosystem, with both insect scavengers and predators living in the fluid (Hua \& Li 2005).

According to the Sarawak Wildlife Protection Ordinance 1998, all Nepenthes spp. are categorized as protected plants in Sarawak. A total of 36 pitcher plant species has been recorded in Borneo (Phillipps et al. 2008). Habitats for Nepenthes spp. are getting scarce due to the opening of areas for development, industrial and agricultural purposes (Coleman \& Hendrix 2000). These habitats are disturbed and destroyed leading to problems in attracting and retaining useful insects to the plants (Kitching 2001). The importance of this study is to obtain primary data regarding fauna species living in close proximity with Nepenthes spp. at Setiam Hill, Bintulu, Sarawak. The objectives of this study were to determine the diversity of fauna trapped in pitcher plants and the relationship between the fauna and the plant. 


\section{MATERIALS AND METHODS}

\section{STUDY AREA}

Observations and field experiments were conducted in November 2013 at Setiam Hill in Tatau, Sarawak, located approximately $50.4 \mathrm{~km}$ from Bintulu Town. The area is $39 \mathrm{~m}$ above sea level at a latitude of $2^{\circ} 58^{\prime} 0.01^{\prime \prime} \mathrm{N}$ and a longitude of $112^{\circ} 55^{\prime} 0.02^{\prime \prime} \mathrm{E}$ (Figure 1). The sampling sites of each Nepenthes spp. were labeled as Setiam $1\left(02^{\circ} 58^{\prime} 10.1 " \mathrm{~N}, 112^{\circ} 55^{\prime} 50.0^{\prime \prime} \mathrm{E}\right)$ for $N$. ampullaria, Setiam $2\left(02^{\circ} 58^{\prime} 11.7 " \mathrm{~N}, 112^{\circ} 55^{\prime} 53.9^{\prime \prime} \mathrm{E}\right)$ for $N$. gracillis, Setiam $3\left(02^{\circ} 58^{\prime} 21.7\right.$ ' N, 112 ${ }^{\circ} 56^{\prime} 11.0^{\prime}$ 'E) for N. reinwardtiana, Setiam 4 (02'59'17.2" N, 112'55'44.3" E) for $N$. rafflesiana and Setiam $5\left(02^{\circ} 59^{\prime} 18.1^{\prime \prime} \mathrm{N}\right.$, $112^{\circ} 55^{\prime} 45.2$ ” E) for N. bicalcarata (Figure 2).

\section{DATA COLLECTION}

As all pitcher plants are categorized as protected species under the Sarawak Wildlife Protection Ordinance 1998, no plant sample was taken out from the study site. The physical characteristics and morphologies of the five Nepenthes spp. were observed and identified based on classification by Clarke and Lee (2004).

A total of five individuals of each Nepenthes spp. were selected randomly and labeled using tagged stickers. Pitcher plants were measured for heights and diameter of lips. The lengths of the pitcher and widths of the peristome (the "lip) width were taken to relate the abundance of fauna found in the plant pitchers with their physical characteristics. Inhale and exhale technique using syringe was adopted to completely collect fluid from the pitcher. Alcohol solution of $72 \%$ concentration was used to preserve samples in

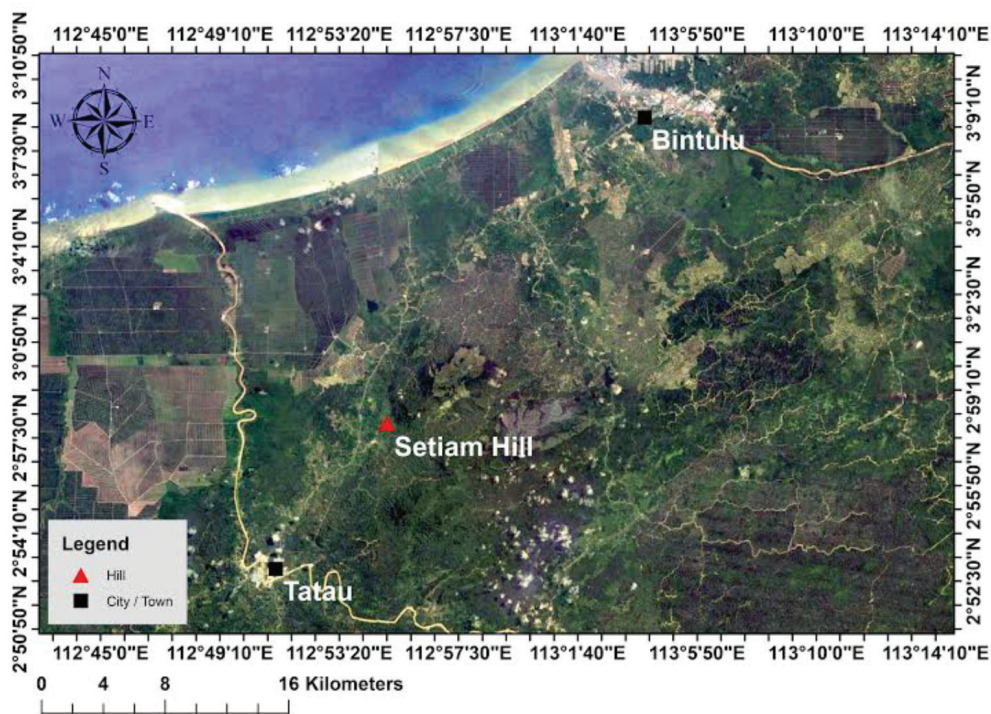

FIGURE 1. Map showing the location of the Setiam Hill

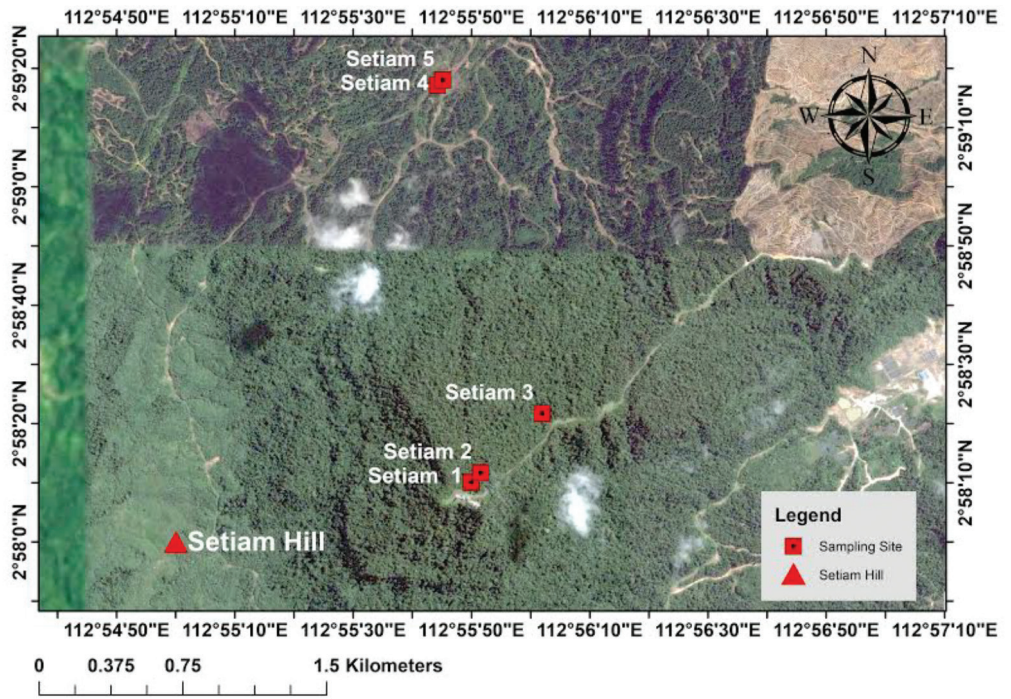

FIGURE 2. Sampling sites for Nepenthes spp 
specimen bottles which were later sealed using parafilm. All samples were observed under dissection microscopes at $20 x-40 \times$ magnification. The physical characteristics and morphologies of the fauna were observed to determine the order and species. The mean percentage abundance was calculated based on the number of individual fauna in traps over the number of pitcher plant by species. The inquilines species number within each pitcher plant species were identified and classified according to their phylum, class, order and their relationships to the Nepenthes spp. The abundance of the fauna in each sample were determined and compared among all samples to determine the type of fauna mostly found in pitcher plants in the area. The distribution patterns of the enumerated fauna were analyzed using SPSS-IBM version 20.0 (SPSS Inc. USA). Comparison of the frequencies of prey taxa between the five pitcher plant species was carried out using Chi-square $\left(\chi^{2}\right)$ tests. Expected frequencies were calculated based on the ratio of total fauna caught between the plant species.

\section{RESULTS}

The five species of Nepenthes in the study area were identified as Nepenthes ampullaria Jack, $N$. bicalcarata Hook. $f, N$. gracilis Korth., N. rafflesiana Jack and N. reinwardtiana Miq. (Figure 3(a)-3(e)). Nepenthes ampullaria was observed to be inhibiting the foreground with clumps of small shrubs and grasses interspersed in patches on bare ground, whereas $N$. gracilis was surrounded by larger shrubs i.e. resam fern (Dicranopteris linearis) which was abundant throughout the area. Nepenthes reinwardtiana was found growing on the hillside and on stone platform besides the road. Meanwhile, $N$. bicalarata and $N$.rafflesiana were found growing close to one another in area which was rocky, open and uncrowded with small shrubs and grasses.

The mean total pitcher peristome width and length of the five Nepenthes spp. are presented in Table 1. The pitcher length showed a trend in the sequence of $N$. rafflesiana $>N$. reinwardtiana $>N$. gracilis $>N$. bicalcarata $>N$. ampullaria while the width of the peristome of each species was of the following trend: $N$. rafflesiana $>N$. bicalcarata $>N$. reinwardtiana $>N$. ampullaria and $N$. gracilis. Both $N$. gracilis and $N$.rafflesiana recorded higher number of fauna captured.

A total of 901 individuals of fauna from eight orders of arthropods were captured in traps of the five pitcher plants species, mostly of the class Insecta and a few nematodes and Araneae. Table 2 shows the number of individual fauna caught in the pitchers. Hymenoptera recorded the highest number of individuals in all species except $N$. reinwardtiana. Several species of ants identified include Camponotus schmitzi (dracula ant), Solenopsis invicta (fire ant), Formica rufa (red wood ant) and Atta cephalotes or (leaf cutter ant). Only the Bornean pitcher plants (Nepenthes bicalcarata) was found to be inhabited by Camponotus schmitzi. Species of sawflies (Argepagana or large rose sawfly and Tenthredopsis scutellaris) were found in the pitchers of N. ampullaria and N. rafflesiana. Only Sphecius speciosus (cicada killer wasp) of the order Hymenoptera was found in N. ampullaria, N. gracilis and N.reinwardtiana. As for the order Diptera, only mosquitoes
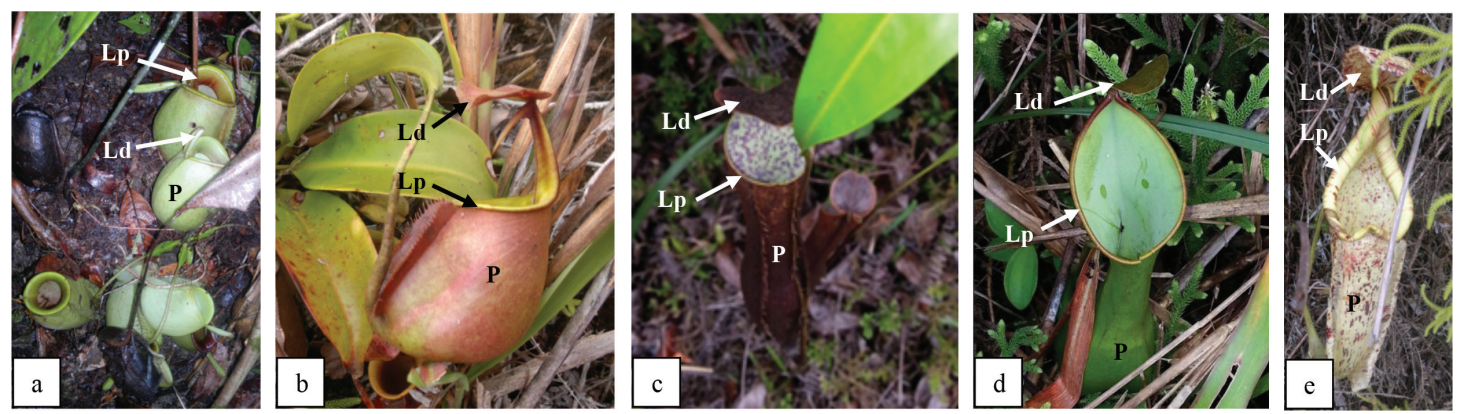

FIGURE 3. Morphology of (a) N. ampullaria, (b) N. bicalcarata, (c) N. gracilis, (d) N. reinwardtiana and (e) N. rafflesiana P: pitcher, Ld: lid, Lp: lip

TABLE 1. Measurements of pitcher length and peristome width for five species of pitcher plants $[$ mean \pm standard error (s.e.)] and the abundance of individual fauna

\begin{tabular}{lccccc}
\hline \multicolumn{1}{c}{ Taxon } & $\begin{array}{c}\text { Length range } \\
(\mathrm{cm})(\mathrm{n}=5)\end{array}$ & $\begin{array}{c}\text { Mean length } \\
(\mathrm{cm})( \pm \mathrm{s} . \mathrm{e} .)\end{array}$ & $\begin{array}{c}\text { Peristome width } \\
\text { range }(\mathrm{cm})(\mathrm{n}=5)\end{array}$ & $\begin{array}{c}\text { Mean peristome } \\
\text { width }(\mathrm{cm})( \pm \mathrm{s} . \mathrm{e})\end{array}$ & $\begin{array}{c}\text { Total individual } \\
\text { fauna captured }\end{array}$ \\
\hline Nepenthes ampullaria & $7.70-10.00$ & $8.90( \pm 0.43)$ & $2.10-3.00$ & $2.62( \pm 0.15)$ & 164 \\
Nepenthes bicalcarata & $7.90-10.10$ & $9.30( \pm 0.38)$ & $3.30-4.60$ & $3.98( \pm 0.25)$ & 137 \\
Nepenthes gracilis & $11.00-13.00$ & $11.86( \pm 0.39)$ & $2.10-3.20$ & $2.62( \pm 0.23)$ & 233 \\
Nepenthes rafflesiana & $7.20-20.00$ & $15.64( \pm 2.47)$ & $3.00-6.00$ & $4.46( \pm 0.58)$ & 232 \\
Nepenthes reinwardtiana & $11.90-15.00$ & $13.12( \pm 0.53)$ & $2.40-3.70$ & $3.00( \pm 0.21)$ & 135 \\
\hline
\end{tabular}


TABLE 2. The abundance of individual fauna in five samples of pitcher Nepenthes spp

\begin{tabular}{|c|c|c|c|c|c|c|c|c|c|}
\hline \multirow[b]{3}{*}{ Taxon } & \multirow{2}{*}{$\begin{array}{c}\text { Phylum } \\
\text { Class }\end{array}$} & \multicolumn{6}{|c|}{ Arthropoda } & \multicolumn{2}{|r|}{ Nematoda } \\
\hline & & & & & Insecta & & & Arachnida & $*$ \\
\hline & Order & Blattaria & Coleoptera & Diptera & Hemiptera & Hymenoptera & Lepidoptera & Araneae & nematode \\
\hline Nepenthes ampullaria & & 1 & 1 & 12 & 0 & 111 & 3 & 1 & 35 \\
\hline Nepenthes bicalcarata & & 1 & 0 & 21 & 0 & 92 & 0 & 0 & 23 \\
\hline Nepenthes gracilis & & 0 & 4 & 29 & 1 & 150 & 0 & 2 & 47 \\
\hline Nepenthes reinwardtiana & & 1 & 4 & 46 & 2 & 41 & 0 & 0 & 41 \\
\hline Nepenthes rafflesiana & & 1 & 6 & 35 & 5 & 136 & 0 & 0 & 49 \\
\hline
\end{tabular}

*Further taxonomy was not determined

(46 individuals) were found in $N$. reinwardtiana. Lepidotera was only found in the Nepenthes ampullaria. Carabidae or the ground beetle of the order Coleoptera was found in most pitchers except for $N$. bicalcarata. Clown beetle or Platysoma leconti was found in pitchers of $N$. ampullaria, $N$. gracilis and $N$. rafflesiana. The Araneae was found in some pitchers of N. ampullaria and N. gracilis. Like Hymenoptera, Nematoda was also found in almost all species.

Most fauna found were identified as prey in the pitcher plant except for the Diptera and nematodes. Most fauna found in the pitcher has the role of being the prey except for Diptera that has been reported to have other relationship with the plant (Table 3) (Figure 4(a)-4(j)).

Table 4 indicates that at least one of the pitcher plants showed significant difference $(\mathrm{p}<0.05)$ in terms of number of individual insect trapped for the order of Hymenoptera, Diptera, Lepidoptera, Hemiptera and nematodes. Meanwhile, no significant difference was observed for the taxa Coleoptera, Blattaria and Araneae.

\section{DISCUSSION AND CONCLUSION}

\section{PITCHER CHARACTERISTICS ON PREY CAPTURE}

The results of this study indicated that pitcher characteristics did not determine the diversity of fauna and number of individual prey captured. Nepenthes rafflesiana with greater peristome width and mean length was found to contain second most number of prey captured after Nepenthes gracilis (Table 1). This contradicts the findings of Darwin (2006) where physical size of pitcher and size of prey were found to be correlated to the number of prey captured. From our observation, the successfulness of prey captured in $N$. gracilis was probably caused by environmental conditions (i.e. topography) where the species was found growing in shaded areas when compared to N. rafflesiana which was found growing in areas that were more open. Wagner (1994) reported that most insects tend to reproduce or lay eggs in shaded area where the place contains high moisture compared to open area that has low moisture. Such moisture can influence the successfulness of the egg to hatch and may disrupt other animals and insects.

\section{RELATIONSHIP BETWEEN PLANTS AND INQUILINES}

Most abundant prey captured belongs to the class Insecta (Table 3) (Figure 4). According to Moran (1999), insects are attracted to pitcher plants because of their nectar secretions and coloration. The slippery rim (peristome) and inner walls of the pitcher caused insects to fall into the digestive fluid at the bottom of the trap. Hymenoptera was found to be the most abundant insect trapped in the pitcher. Most species of Hymenoptera can be recognized as prey but some ants gained benefits from the pitcher.

TABLE 3. Taxa of arthropods found in traps of five pitcher plants species, showing relationship of fauna to plants and relative abundance $(\%)$ in traps for individual taxa

\begin{tabular}{lllccl}
\hline Phylum & \multicolumn{1}{c}{ Class } & \multicolumn{1}{c}{ Order } & Total & Abundance (\%) & \multicolumn{1}{c}{ Relationship } \\
\hline Arthropoda & Insecta & Hymenoptera & 530 & 58.82 & Prey or mutualistic \\
& & Diptera & 143 & 15.87 & Habitat, reproduction and parasites \\
& & Lepidoptera & 3 & 0.33 & Prey \\
& & Coleoptera & 15 & 1.66 & Prey \\
& & Blattaria & 4 & 0.44 & Prey \\
& \multirow{2}{*}{ Arachnida } & Hemiptera & 8 & 0.89 & Prey \\
Total & Araneae & 3 & 0.33 & Prey or other effect (predator) \\
\hline
\end{tabular}

*Further taxonomy was not determined 


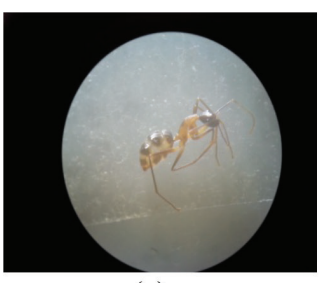

(a)

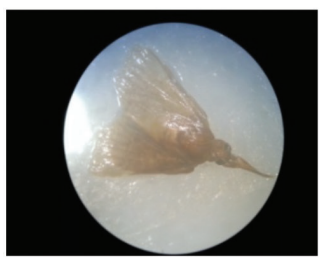

(e)

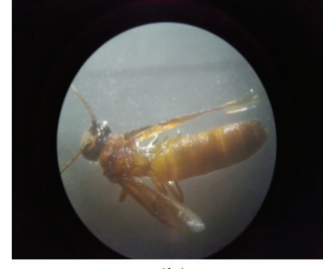

(b)

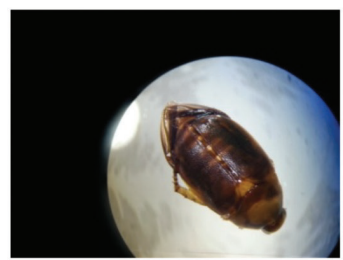

(f)

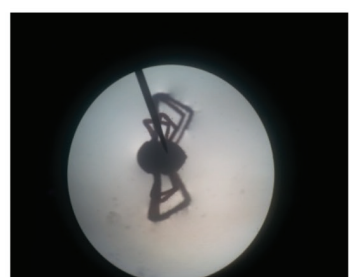

(i)

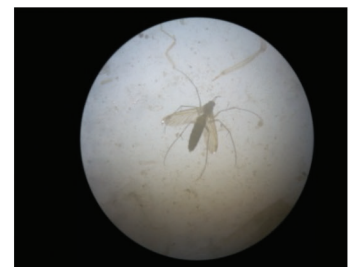

(c)

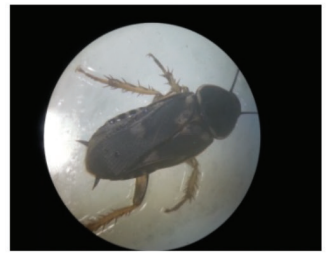

(g)

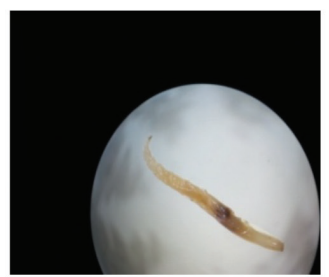

(j)

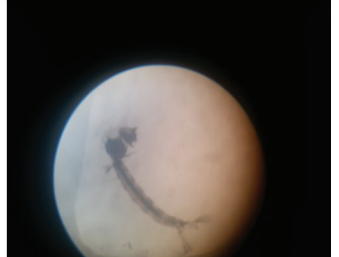

(d)

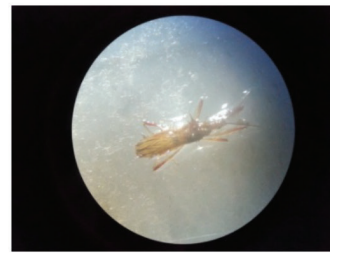

(h)

FIGURE 4. Fauna captured in traps of pitcher plant: Hymenoptera: (a) ant, (b) wasps, Diptera: (c) adult mosquito, (d) mosquito larvae; Lepidoptera: (e) moth; Coleoptera: (f) beetle; Blattaria: (g) cockroach; Hemiptera: (h) bug; Arachnida: (i) Araneae; and (j) nematode

TABLE 4. Comparison of fauna composition in Nepenthes species

\begin{tabular}{lccccccc}
\hline \multirow{2}{*}{ Fauna } & N. ampullaria & N. bicalcarata & N. gracilis & N. reinwardtiana & N.rafflesiana & \\
\cline { 2 - 7 } & Mean $( \pm$ s.e $)$ & Mean $( \pm$ s.e $)$ & Mean $( \pm$ s.e $)$ & Mean $( \pm$ s.e $)$ & Mean $( \pm$ s.e $)$ & $\chi^{2}$ & $\mathrm{P}$ \\
\hline Hymenoptera & $22.20( \pm 7.29)$ & $18.40( \pm 5.16)$ & $30( \pm 6.30)$ & $8.20( \pm 2.87)$ & $2.72( \pm 8.22)$ & 68.69 & $<0.05$ \\
Diptera & $2.40( \pm 1.29)$ & $4.20( \pm 1.98)$ & $5.80( \pm 3.87)$ & $9.20( \pm 3.76)$ & $7( \pm 3.31)$ & 23.67 & $<0.05$ \\
Lepidoptera & $0.60( \pm 0.89)$ & 0 & 0 & 0 & 0 & 12 & $<0.05$ \\
Coleoptera & $0.20( \pm 0.20)$ & 0 & $0.80( \pm 0.58)$ & $0.80( \pm 0.49)$ & $1.20( \pm 0.8)$ & 7.99 & $\mathrm{~ns}$ \\
Blattaria & $0.20( \pm 0.20)$ & $0.20( \pm 0.20)$ & 0 & $0.20( \pm 0.2)$ & $0.20( \pm 0.2)$ & 1 & $\mathrm{~ns}$ \\
Hemiptera & 0 & 0 & $0.20( \pm 0.20)$ & $0.40(0.24)$ & $1( \pm 0.63)$ & 10.75 & $<0.05$ \\
nematode & $7.00( \pm 2.92)$ & $4.60( \pm 2.27)$ & $9.40( \pm 3.82)$ & $8.20( \pm 2.69)$ & $9.80( \pm 3.87)$ & 11.28 & $<0.05$ \\
Araneae & $0.20( \pm 0.20)$ & 0 & $0.40( \pm 0.24)$ & 0 & 0 & 5.33 & $\mathrm{~ns}$ \\
\hline
\end{tabular}

Note: Proportions of fauna types compared using Chi-square $\left(\chi^{2}\right)$ tests. ns $=$ Not significant, where $p>0.05$

Camponontus schmitzi found in pitchers of $N$. bicalcarata may have used the pitcher as a place to gather food source as they can eat all the larvae in the pitcher (Clarke $\&$ Kitching 1993). The second most abundant fauna found was the parasitic nematodes. Nematodes have been known to consume inorganic nutrients dissolved in pitcher plants (Chittka 1996). The Araneae found in pitchers of $N$. ampullaria and $N$. gracilis may have used the pitcher as a breeding site that suit the habitat for its offspring besides providing a trap to capture its prey. The crab spider (Misumenops nepenthicola) was also found in this study. Beaver (1983) reported that the spider commonly sealed the opening of the pitcher and this strongly reduced its trapping efficiency (Cresswell 1998). Meanwhile, the mosquito larvae mostly found in the pitcher are parasites that obtained nutrients from the Nepenthes spp. (Kitching 2000).

\section{COMPARATIVE EFFICIENCY IN TRAPPING ANTS}

Hymenoptera was by far the most diverse order found in this study. Their high mobility, combined with welldeveloped eyes and sense of smell, enable them to find pitchers for oviposition, thus promoting their eminent success (Cresswell 1998). Other organisms do pay a visit but do not constantly inhabit the pitchers. These visitors are normally not retained, and they enter the traps sporadically for shelter or to feed on the plant's prey. Ants are found to be the major prey group in all pitcher species, accounting for over $58.82 \%$ (Table 3 ) of the total prey in the traps. There were two main components contributing 
to this ant-specialization, namely the nectar source and an apparently efficient trapping mechanism (Moran 1999). Ants are highly attracted to sugar, which are present in high concentration in the form of nectar. Nepenthes gracilis provided efficient pitfall traps in trapping prey besides being attractive to invertebrates (Juniper et al.1989; Moran 1999). The peristomes which are normally depicted as far from being a slippery perch, sometimes provides a remarkably safe platform from which creatures can feed at the marginal glands. However, when a creature ventures into the inner wall of the pitcher, it is in danger of losing its foothold. According to Kato et al. (1998), the fact that ants transmit information about food resources to their colony, predisposes them to utilize the Nepenthes pitcher in the manner.

\section{MECHANISMS OF SELECTIVITY IN NEPENTHES PITCHER}

The frequency of prey organisms passing within the range of the traps will depend on factors such as their abundance in the area, mobility and whether there is attraction (or avoidance) to the traps. Research have suggested that mucilage secreted by external glands around the door and the sweet fragrant produced by $N$. rafflesiana may act as attractant for its prey (Lloyd 1942; Moran 1999).According to Protocor (1999), differences in prey catchability could lead to either over-representation or under-representation in the trap fauna. The under-representation of Lepidoptera in the traps may be caused by their flight ability and habits where they are more attracted to flowers thus making them more difficult to be trapped (Wagner et al. 1994). Although some plants do have similar capability of capturing fauna, the total number of individuals captured differ e.g. Hymenoptera was found in all pitcher plant species but the number was highest in $N$. gracilis. Furthermore, some plants do not even have the species of fauna found in another e.g. Lepidoptera was only found in N. ampullaria. Generally, the fauna species found in this study may have formed a predator-prey, a parasitic or even a mutualistic relationship with the pitcher plant.

\section{ACKNOWLEDGEMENTS}

The authors would like to thank Department of Forestry Science, Faculty of Agriculture and Food Sciences, Universiti Putra Malaysia Bintulu Sarawak Campus and its staff for the use of equipment, guidance and assistance. Not to forget Mr. Hasnan Md Isa, final year student of Diploma in Forestry, Department of Forestry Science for his helping hand in the field.

\section{REFERENCES}

Adam, J.H. 2002. Ecology and diversity of pitcher plants in Sarawak. Proceedings The 4th International Carnivorous Plant Conference Tokyo, Japan. pp. 165-169.

Adam, J.H. 1995. Abstracts Biotechnology of the 4th ASEAN Science and Technology Week. Science and Technology: The Future of ASEAN, Bangkok. 21 August-1 September 1995. pp. 39-48.
Beaver, R.A. 1983. The communities living in Nepenthes pitcher plants: Fauna and food webs. Terrestrial Plants as Hosts for Aquatic Insect Communities. Medford: Plexus Publishing.

Chittka, L. 1996. Optimal sets of color receptors and color opponent systems for coding of natural objects in insect vision. Journal of Theoretical Biology 181(3): 17-196.

Clarke, C. \& Kitching, R.L. 1993. The metazoan food webs from six Bornean Nepenthes species. Ecological Entomology 18: 7-16.

Clarke, C. 2001. Nepenthes of Sumatra and Peninsular Malaysia. Kota Kinabalu: Natural History Publications (Borneo).

Clarke, C. 1997. Nepenthes of Borneo. Kota Kinabalu: Natural History Publications.

Clarke, C. \& Lee, C. 2004. A Pocket Guide Pitcher Plants of Sarawak. Kota Kinabalu: Natural History Publications (Borneo).

Cresswell, J.E. 1998. Morphological correlates of necromass accumulation in the traps of an Eastern tropical pitcher plant, Nepenthes ampullaria Jack, and observations on the pitcher infauna and its reconstitution following experimental removal. Journal of Ecology 113(21): 383-390.

Coleman, M. \& Hendrix, H.B. 2000. Development and civilization of agriculture. Journal of Botany 3: 4-1.

Darwin, C. 2006. Insectivorous plants: Functional characteristics of traps of Utricularia species. Journal of Aquatic Botany 95(3): 226-233.

Hua, Y. \& Li, H. 2005. Food web and fluid in pitchers of Nepenthes mirabilis in Zhuhai, China. Acta Botanica Gallica 152(2): 165-175.

Juniper, B.E., Robins, R.J. \& Joel, D.M. 1989. The Carnivorous Plants. London: Academic Press.

Kato, K., Sota, T. \& Mogi, M. 1998. Local and regional-scale food web structure in Nepenthes alata pitchers. Journal of Botany 30(7): 82-91.

Kitching, R.L.2001. Food webs in phytotelmata. Annual Review of Entomology 67(46): 729-760.

Kitching, R.L. 2000. Food Webs and Container Habitats. The Natural History and Ecology of Phytotelmata. Cambridge: Cambridge University Press.

Lloyd, F.E. 1942. The Carnivorous Plants. New York: Chronica Botanica. p. 352.

Moran, J.A. 1999. Aspects of pitcher morphology and spectral characteristics of six Bornean Nepenthes pitcher plant species: Implications for prey capture. Journal of Botany 83(5): 521-528.

Phillipps, A., Lamb, A. \& Lee, C.C. 2008. Pitcher Plants of Borneo. 2nd ed. Kota Kinabalu: Natural History Publications.

Protocor, N.N. 1999. Forests characteristics the ecology and the living things. Journal of Forestry 44(2): 241-245.

Wagner, M., Aßmus, B., Hartmann, A., Hutzler, P. \& Amann, R. 1994. In situ analysis of microbial consortia in activated sludge using fluorescently labeled, rRNA-targeted oligonucleotide probes and confocal scanning laser microscopy. Journal of Microscopy 176(24): 181-187.

\section{M.T. Marina*}

Faculty of Science, Universiti Putra Malaysia

43400 UPM Serdang, Selangor Darul Ehsan

Malaysia

C. John Keen, B.R. Caroline \& J. Afsar

Faculty of Agriculture and Food Sciences 
Universiti Putra Malaysia

Bintulu Sarawak Campus

97008 Bintulu, Sarawak Bumi Kenyalang

Malaysia
*Corresponding author; email: marinamohd@upm.edu.my

Received: 30 August 2016

Accepted: 15 June 2017 